ARTICLE

\title{
Life Masquerading as Art: The Activist Artist Takes on Development v. Environment
}

\author{
Hubert Devonish and April Baptiste ${ }^{2}$ \\ ${ }^{1}$ University of the West Indies, Mona, JM \\ ${ }^{2}$ Colgate University, US \\ Corresponding author: Hubert Devonish (hubert.devonish@uwimona.edu.jm)
}

The paper questions the role of the transformative artist within Caribbean popular culture with reference to the costumed "Mas" bands in Trinidad Carnival, using Fanon's argument on the role of the artist as the theoretical base. Using the documentary "The Minshall Trilogy: A Modern Fable as Street Theatre" as its source of visual and contextual data on these bands, the paper examines how the artist, Peter Minshall, takes the traditional folk worldview of an agrarian 19th century Trinidad and converts it into a late 20th century discourse on industrial development, materialism, moral vales and development.

Keywords: Artist; Trinidad; environment; worldview; development; Minshall

\section{Introduction}

The question of the role of the artist in transforming society is an age old one, as is that role in the transformation of the 20th- and 21st-century postcolonial societies in Asia, Africa, and the Caribbean. In different contexts, this debate plays itself out in different ways. In the rapidly industrializing Caribbean, Trinidad and Tobago, in the late 20th-century provides a particularly interesting context within which this age-old debate takes place. Of interest is the fact that the artist in question, Peter Minshall, is operating not in an elitist art form, but in a mass based one. This is one, which involves the design, and presentation of Carnival costumed bands. Significantly, the issue, which he is addressing, is the very current one of industrialization/development versus the environment. In tackling the problem through art, the artist claims to repackage mass consciousness in a way that raises the level of that consciousness. His clear intent is that this changed consciousness would be converted into a changed outlook on the part of the mass of the population. This change would force the state to have the preservation of the natural environment at the center of its plans for economic development.

This paper takes as its starting point the proposals by the Caribbean theoretician of anti-colonial struggle, Frantz Fanon, concerning the role of the artist in the creation of a national culture in post-colonial societies. ${ }^{1}$ It studies the way in which Minshall takes traditional culture, very much in the mode proposed by Fanon, and turns it into art which addresses new and currently relevant issues. More particularly, there is a systematic examination of the structure and content of the worldview represented by traditional culture, and the new one, which the artist is trying to bring into being via his art. There is, finally, treatment of the artist's works' impact on the society and the level of popular consciousness on the question of economic development and the natural environment.

\subsection{Peter Minshall as Activist Artist}

Peter Minshall is a Guyana-born Trinidadian costume designer with an international reputation. He designed costumes for the displays, which opened the Atlanta Olympics and several football World Cups. From an artistic point of view, and from the perspective of its importance to the people of his homeland, Trinidad

\footnotetext{
${ }^{1}$ Frantz Fanon, The Wretched of the Earth (New York: Grove Press, 1968), 206-248.
} 
and Tobago, his designs for the Trinidad Carnival Mas bands, 1983-85, which have become known as "The Trilogy," stand out.

A Dalton Narine video documentary entitled "The Minshall Trilogy: A Modern Fable as Street Theatre" covers the groundbreaking Mas Bands designed and presented by Peter Minshall over a period of three years, 1983-85. These bands are respectively "River" in 1983, "Callaloo" in 1984 and "Golden Calabash" in 1985. Towards the end of the documentary, Minshall comments on his creative and artistic intent in relation to "The Trilogy." In doing this, Minshall refers by name to the activist poet of the Spanish Civil War, Frederico Garcia Lorca, reciting the following lines from one of Lorca's poems:

The poem, the song, the picture is only water drawn from the well of the people, and it should be given back to them in a cup of beauty so that they may drink - and in drinking, understand themselves. $^{2}$

Minshall, by choosing Lorca as a medium through he explains his own work gives us a key to understanding "The Trilogy."

Lorca was a poet who sided with the Spanish Republic against the Nationalists. In the earlier part of his career, he engaged in creating modern poetry based on the folksongs of Spain. In the latter part, he headed a touring theatre company, which travelled around Spain exposing the poor and dispossessed to the transformative effects of art. Like Fanon and Ngugi, ${ }^{3}$ Lorca saw the artist as central to the struggle for change. In addition, the intentions of the Trilogy to address the practical concerns of the people of Trinidad and Tobago are made clear by Minshall who, in the Narine documentary film, describes this body of his work as an allegorical tale of Trinidad and Tobago.

Given the above, what is this "water" that, in the metaphor of Lorca, exists in the well of the people? This is critical to understanding "The Trilogy" since water, in the form of rivers, is a foundational metaphor of "The Trilogy," itself. And what is the difference between water as it exists in "the well of the people" and when it becomes re-presented to them in "a cup of beauty." The artist's contribution to this process is "the cup of beauty." Minshall sees his own role as helping people to understand themselves, and using this understanding to transform their own reality. Our interest here is firstly the original water that is drawn from the well of the people. What does this represent in terms of the people's understanding of themselves and the way they see the world within their folk traditions? And what is the new image of themselves, with reference to their modern conditions that the people see in the water in the "cup of beauty" that they do not see in the well water? In arriving at an answer to the second question, we will have to seek an answer to a third. What role does the "cup of beauty" play in the transformation of the water, and in the self-understanding of the people?

The answer to the above question may very well lie in another literary quote, one which forms part of the oral narration accompanying the parading across the stage of "Golden Calabash," the last band in "The Trilogy." The quote is from R.D. Laing's writing in psychiatry and, as some would say, mysticism, "I have seen the Bird of Paradise. She has spread herself before me and I shall never be the same again." ${ }^{4}$ The Bird of Paradise is a costumed character in the "Golden Calabash" Mas band, functioning in a context in which it represents an extraordinary presence, outside the experience of nearly everyone living in Trinidad and Tobago at the time. One theme in the Laing work is that of the difficulties faced in trying to know one's self and to know the external world. He argues that, to know, one has to have an experience. This creates problems for communicating such knowing to someone who did not have the experience, which produces such knowing. If Minshall has seen the Bird of Paradise and has been transformed by that experience, his only hope of communicating the knowledge he has got from this experience is to create a new one for his target audience, the people of Trinidad and Tobago. This, we suggest, he does through the creation of a shared experience involving a mass participation art form, Trinidad Carnival Mas. ${ }^{5}$ This experiential art form is the cup of beauty containing the water taken from the well of the people.

The notion of the artist as an activist with the goal of transforming society was not strange to the Trinidad and Tobago of 1983 within which Minshall was to mount his Trilogy. The failed 1970 Black Power Revolution

\footnotetext{
${ }^{2}$ The Minshall Trilogy: A Modern Fable as Street Theatre, directed by Dalton Narine (2010; Port of Spain, Trinidad and Tobago: Create Space Studio), DVD.

${ }^{3}$ Ngũgĩ wa Thiong'o, Barrel of a Pen: Resistance to Repression in Neo-Colonial Kenya (London: New Beacon Books, 1983$), 57$.

${ }^{4}$ Robert D. Laing, The Politics of the Experience (New York: Ballantine Books, 1967), 190.

5 James Aronson, "What is effective in restoration ecology and how to measure it," in On Effectiveness: Studies on the Nature of War, ed. Giorgio Ausenda (Woodbridge: Boydell Press, 2003), 67.
} 
in Trinidad and Tobago had a fundamental influence on much that took place in that country over the following two decades. ${ }^{6}$ In describing the ideological influences on the youth who made the Revolution, Khafra Kambon, previously Dave Darbeau, one of the leading figures of the Revolution, states, "Frantz Fanon's technically-worded Wretched of the Earth was broken down by dictionaries, discipline, dedication to understanding the psychological damage of colonialism, and the thirst for liberation." ${ }^{7}$

Fanon was a Martiniquan psychiatrist who fought in the Algerian Independence War, and became a theoretician of the process of decolonization. He addresses, in his chapter on national culture, the role of the artist in a context of resistance to colonialism and neo-colonialism. The artist in that situation is presented as playing the role of helping to construct the national identity of the newly independent and, importantly for him, modern state. For him, however, the building blocks are inevitably the traditional art forms used by the people of a nation. Fanon insists, nevertheless, that a national culture is not folklore even though it uses folk forms such as traditional stories, epics, and songs. ${ }^{8}$ The artist, active in creating a national culture, rather than repeating unchanged the forms handed down from generation to generation, modifies them and brings them to life by associating them with issues which are modern and current. "There is a tendency to bring conflicts up to date and to modernize the kinds of struggle which the stories evoke, together with the names of the heroes and the types of weapons.." ${ }^{\prime \prime}$ Allusion, involving the use of the traditional to refer to the current and modern, becomes a key element in art produced in this context. The end point of this process is that the activist artist "... turns himself into an awakener of the people; hence comes a fighting literature, and a national literature." ${ }^{10}$ This description, however, does not allow us to distinguish properly between activist art, on one hand, and political propaganda on the other.

A solution might be found in the Lorca metaphor of dipping from the well of the people and giving that water back in a cup of beauty. Does the water from the well of the people taste any different when presented back to the people in a beautiful cup, or in Minshall's case, a Golden Calabash? And if there is a difference, what precisely is it? The water from the well of the people is a double metaphor, standing both for the traditions of the people and their everyday, lived experience. The water, which they drink out of the "cup of beauty," in turn, is firstly a conversion of the folk traditions, Fanon style, into "national culture." It is, at the same time, the re-presenting of the lived experience in a form, which allows for reflection and action to change reality. It is this phenomenon of what we call, "life masquerading as art," that this paper seeks to explore. The ultimate goal is to highlight how art in its various forms drawing from the perspective of the "real" world, may have the capacity to effect changes in public attitudes on the issue of "development versus the environment."

Based on Minshall's reference to the Lorca poem, he would logically have to carry out three operations to achieve his activist objective. He first has to dissolve the wall between reality and art created by the artist, allowing the water from the well to be the same as the water in the "cup of beauty." In addition, the "cup of beauty" fashioned by the artist has to perform two roles. It must re-present the real life issue in a form that is a lot clearer and easier to understand than it was in real life. In addition, this re-presentation should be in the form of an actual experience, creating the emotional charge required for that the target group, the public, to feel obliged to act.

This paper, therefore, has three components. It first explores "the water in the well of the people" from the perspective of the oral folk tradition. The second component examines "water presented in the cup of beauty/golden calabash" and how that presentation both uses and alters that which originally came from the well. The third involves the cup/calabash itself since the presentation of the water relies for its effect on the cup/calabash within which it is contained. Any examination of the contents of the container has to be integrated with a consideration of the art that fashions that container. That art is one that merges the reality of "the people" with the fantasy of the Mas, to attempt to achieve changed attitudes and behaviors in the "real" world. Through a study of these three components, we can develop a clear sense of how the self-knowledge was made available via the contents of the cup/calabash. This in turn gives us a snapshot of what a "national culture," in the sense used by Fanon, ${ }^{11}$ might produce as a result of an artist

\footnotetext{
${ }^{6}$ Victoria Pasley, "The Black Power Movement in Trinidad: An Exploration of Gender and Cultural Changes and the Development of a Feminist Consciousness," Journal of International Women's Studies 3, no. 1 (2001): 25-26. http://vc.bridgew.edu/jiws/vol3/ iss $1 / 2 /$.

7 Khafra Kambon, “Ken Valley, black power and Africa," Trinidad Express, May 19, 2011, http://www.trinidadexpress.com/commentaries/ken_valley_black_power_and_africa-122207593.html.

${ }^{8}$ Fanon, The Wretched of the Earth, 188.

9 Ibid., 193.

${ }^{10}$ Ibid., 179.

${ }^{11}$ Fanon, The Wretched of the Earth, 206-248.
} 
working in this activist tradition. This "national culture" is both the "worldview" developed and adapted in the face of changing circumstances, and the cultural systems of interaction and transmission, which produce it.

\subsection{The Context}

The economy of Trinidad and Tobago, in the 19th- and first few decades of the 20th- century was characterized by a rural based plantation mode of production. Agro-based products such as cocoa and, more importantly, sugar, were produced for export. The predominant character of the society was rural and agrarian. The worldview of this society was reflected in a very well developed oral folk tradition, which will be examined in the course of this paper. In the mid 20th-century, there was a shift to an economy based on the extraction of petroleum and later natural gas for export. The late 20th-century saw a further shift, this time to full industrialization and the production of secondary and tertiary goods, notably petrochemicals and iron and steel, using hydrocarbons as input and energy source. ${ }^{12}$

The switch from an agrarian to an industrial society is captured by the Point Lisas Development Corporation's website quote of Eric Williams, the first Prime Minister of Trinidad and Tobago and proponent of industrialization. Williams stated, at the 1977 sod turning ceremony for the Iron and Steel Company of Trinidad and Tobago (ISCOTT), “... our presence today at Point Lisas testifies to the fundamental change that has taken place in the world economy and in the economic balance of power ... here at Point Lisas sugar cane gives way to wire rods." ${ }^{13}$ This echo of the biblical beating of swords into ploughshares, involving the planting of wire rods where sugar cane stalks used to grow, heralded the transition from an economy based on the production of natural agricultural products to one involving heavy industrial manufacturing. The rate of industrialization was such that, by 2009, Trinidad and Tobago had moved from being an underdeveloped country relying on exports of sugar and petroleum to the world's second largest per capita emitter of carbon dioxide, topped only by Qatar. ${ }^{14}$

Typically, this shift in mode of production is accompanied by a shift in cultural attitudes to nature and the environment. ${ }^{15}$ By 1983, this shift in values was well established in Trinidad and Tobago with a massive rise in consumerism and conspicuous consumption. ${ }^{16}$ As often happens with big changes, there was opposition and radical critique. The critique in the Trinbagonian case revolved around the negative environmental and other effects of industrial capitalist production. Our interest is to explore in this paper the aforementioned radical critique, at the level of popular culture, to these consumerist changes.

Arguably, the most salient and significant manifestation of Trinidad and Tobago popular culture has been its annual Carnival. The new consumer ethos was manifested, at the level of popular culture, by a highly commoditized, tourist oriented Carnival celebration, and its dominant manifestation, "fancy" Mas. ${ }^{17,18}$ The critique offered by Minshall's art, to the rapid embracing of consumerism employs a medium that, from the perspective of modern environmental activism, is unusual. The critique of the rapid embracing of consumerism provided by Minshall's art takes place in a medium that, from the point of view of modern environmental activism, is unusual. Using the popular, participatory and visible medium of Carnival Mas, Minshall attempts to deal with the environmental issues then facing the country. These are presented in the form of a traditional tale of what was and the new world that is coming. Critics openly attack the Trilogy; arguing that true Carnival Mas is pure fantasy, total escape from the real world. They consider that Minshall is illegitimately injecting that real world into the fun and joy of Carnival Mas. ${ }^{19}$ An analysis of Minshall's message and his method of conveying such message are presented in the following sections.

${ }^{12}$ Francisco E. Thoumi, "Thwarted Comparative Advantage, Economic Policy and Industrialization in the Dominican Republic and Trinidad and Tobago," Journal of Interamerican Studies and World Affairs 3, no. 1\&2 (1989): 147-68, DOI: https://doi. $\operatorname{org} / 10.2307 / 165915$.

${ }^{13}$ PLIPDECO, "A world-class development: The Point Lisas Industrial Estate and the Port of Point Lisas contributing to national development for 45 years," Point Lisas Industrial Port Development Corporation Limited, 2012, http://www.plipdeco.com/main/uploads/ files/Plipdeco_a_Wold_\%20Class_Development.pdf.

14 T.A. Boden, G. Marland and R.J. Andres, "Global, Regional, and National Fossil-Fuel $\mathrm{CO}_{2}$ Emissions," Carbon Dioxide Information Analysis Center, 2011, http://cdiac.ornl.gov/trends/emis/tre_amd.html.

${ }^{15}$ Ronald Inglehart, Modernisation and PostModernisation: Cultural, Economic and Political Change in 43 Societies (Princeton: Princeton University Press, 1997), 3-6.

16 Pasley, Black Power Movement, 24.

17 Peter Manuel, Kenneth Bilby and Michael Jargey, Caribbean Currents: Caribbean Music From Rumba to Reggae (Philadelphia: Temple University Press, 1995), 204-205.

18 Robert Burton, Afro-creole: power, Opposition and Play in the Caribbean (Ithaca: Cornell University Press, 1997$), 208$.

${ }^{19}$ Narine, Minshall Trilogy. 


\section{Reconstructing a Traditional Trinbagonian Worldview}

The three bands of the Trilogy ("River," 1983; "Callaloo," 1984; “The Golden Calabash," 1985) contained a key element, the use of traditional Trinidad and Tobago folklore characters and folk motifs. These folk traditions and the worldview, which they represented, developed and thrived within the rural and agrarian Trinidad of the 19th- and early 20th-centuries. Toelken suggests that the body of folk traditions of a community can be used to construct an image of the worldview of that community. ${ }^{20}$ This we will seek to do for the early community to which this folk tradition belonged. We are interested in those aspects of traditional worldview that Minshall, as artist and designer, was reaching into the past for, in order to construct his modern critique. The particular aspects of Trinidad folklore, which Minshall extracts for use in the Trilogy, points us to those features of the traditional Trinidadian worldview he was seeking to inject into his very modern artistic creation.

Worldviews typically consist of a) an explanation of the world, b) a prediction about the future of the world, c) ethics, i.e. what is the right thing for us to do, d) a theory of action, i.e. how to attain our goals, e) epistemology, what is true or false, and f) etiology, an account of the building blocks of the constructed worldview, i.e. its origins and how it was constructed. ${ }^{21,22}$ We use these characteristics to examine a batch of Trinbagonian traditional folk stories relevant to the Minshall Trilogy. These stories typically are about two main characters, Papa Bwa (Bois), "Father Forest" in Trinidad and Tobago French-lexicon Creole, and Maman Dlo (Glo) "Mama Water" in that same language. There is a third significant character, Ti Jeanne, the Washerwoman/Blanchisseuse. The versions of these stories we work with are taken from a collection of folk stories and legends presented in Besson. ${ }^{23}$ The relevant oral folk traditions cover the relationship between humans and the environment, and more broadly ethical issues such as good and evil.

When Papa Bwa was born, both the sun and moon were visible in the sky. Born in some distant land, he came to Trinidad and Tobago when he was young. His family died on the way and he was marooned possibly on the north coast of Trinidad. As a child, Papa Bwa did not have a name and became known as "I," "mwen" in the French-Creole in which these stories were originally told. He learnt to communicate with the animals of the forest, eventually seeing himself as part of the forest. He was known for warning the animals of impending danger from hunters. Papa Bwa had special traits, which allowed him to change form, becoming plant or animal at will. In some stories, he turns into a humming bird, a tree, a deer, and eventually into the land itself. There is no separation between him (I/Papa Bwa) and the physical environment. Physically, Papa Bwa had the upper body of a man and the lower body of a hooved creature and was very hairy. ${ }^{24}$

We get an emerging theme here of a unity between man and nature. He is half man and half animal. Nature, specifically the forest, protects him as a child marooned and without parents. He, in turn, protects the animals of the forest, given his superior ability to detect impending danger. The name he becomes known by as a child to the creatures of the forest, "I"/"mwen," places him at the center of all he beholds, since "I" can only refer to the beholder. To be "I" requires consciousness and to have no other name than "I" suggests that he is the only conscious being within the situation. In that sense, all nature revolves around the beholder. He, "I," therefore, although a creature in the forest, is a very special one, the conscious one. Papa Bwa eventually falls in love with a mermaid, though there is no indication of him actually being married to/or being the lover of this mermaid. He is typically presented as the lover of Maman Dlo, literally "Mother Water/the mother of the water." 25

Maman Dlo is considered the protector of the forest and the water. She has the body of a snake, specifically an anaconda and the face of an African woman. She is said to be hideous and to wear large earrings. In other story versions, she appears as a beautiful woman. She is believed to be the lover of Papa Bwa. As protector of the forest and water, she punishes anyone who harms animals and plants in the forest indiscriminately. The punishment for men is to be permanently married to her, both in this life and in the afterlife. ${ }^{26}$ The themes are similar to the ones for Papa Bwa. We have the unity with nature in the form of a body, which is only half

\footnotetext{
${ }^{20}$ Barre Toelken, The Dynamics of Folklore (Logan: Utah State University Press, 1996), 2.

${ }^{21}$ Karanja Keita Carroll, "A Genealogical Analysis of the Worldview Framework in African-centered Psychology," Journal of Pan African Studies 3, no 8 (2010): 109-34. http://go.galegroup.com/ps/i.do?id=GALE\%7CA306596725\&v=2.1\&u=nysl_ce_colgul\&it=r\&p=L itRC\&sw=w\&asid=a33117b060862e0b2758cc30f8c6a7f8.

${ }^{22}$ Kathryn A. Johnson, Eric D. Hill and Adam B. Cohen, "Integrating the Study of Culture and Religion: Toward a Psychology of Worldview," Social and Personality Psychology Compass 5, no. 3 (2011): 137-52, DOI: https://doi.org/10.1111/j.1751-9004.2010.00339.x.

${ }^{23}$ Gerard Besson, Folklore and legends of Trinidad and Tobago, San Juan, Trinidad: Paria Publishing Company Ltd, 2001).

${ }^{24}$ Besson, Folklore and legends, 11-19.

${ }^{25}$ Ibid, 50.

${ }^{26}$ Ibid, 48-51.
} 
human, and this time part snake. She too protects nature. Whereas Papa Bwa is the protector of the land, she is the protector of the water.

One particular story relevant to the Trilogy is that of Ti Jeanne, a young woman from Blanchisseuse, a place name which itself means Washerwoman. Ti Jeanne goes to a river to do laundry. After washing the clothes, she lays them on the rocks to dry. While waiting, she stares at herself in the river water admiring her beauty. Maman Dlo interprets this staring to be a manifestation of vanity and appears to her. Though Ti Jeanne explains that she respects the water and does not kill anything, Maman Dlo indicates that vanity is a sin. She mesmerizes Ti Jeanne and turns her into a mermaid. She is made to serve Maman Dlo for life as a punishment. ${ }^{27}$ Here we see an extension of the roles of these folk characters. From protecting nature, they go even further and punish those who show lack of virtue, in this case the sin of vanity.

These stories, a small sub-set of the body of material making up traditional Trinidad and Tobago folklore, show all of the characteristics associated with a worldview. We find out how the world, specifically Trinidad, comes into existence in the sense of being part of the consciousness of the characters that inhabit it. Papa Bwa, the main character, enters the world in special circumstances, with both the sun and the moon visible in the sky. Notionally, Trinidad comes into being by Papa Bwa being marooned on it. This represents worldview characteristic a), the notion of how the world came into being is present in the story collection. Other characteristics of worldview can be found in the body of oral traditions. In terms of characteristic b), a prediction about the future of the world, punishment awaits anyone who harms nature. To achieve one's goals, one must make common cause with nature and be virtuous. Virtue must include a personal element, that of being humble rather than vain.

There is, as well, characteristic c), ethics, within the folk traditions presented. Animals and plants should not be killed indiscriminately. Whosoever violates this rule is punished. The implication here is that humans should have respect for life. It is worth noting that there is hierarchy within the ethical realm. The evil of vanity is severely punished, even when one is virtuous by respecting nature and killing nothing.

The oral tradition also contains within itself characteristic d) a theory of action. In order to prosper, one needs to make common cause with nature. There is within the oral tradition an explicit statement on truth and falsehood. This is characteristic e). Mama Dlo punishes Ti Jeanne for a very specific expression of vanity. Ti Jeanne is giving great value to something that is not real, a reflection of herself in the water.

The Trinidad oral tradition passes on, within it, a sense of how the worldview associated with this lore is constructed and comes into being. This is, after all, a body of lore and belief handed down by the old people, based on their own experience and wisdom, expressly for the benefit of a younger generation. This is characteristic f), etiology. It serves to contextualize the entire body of lore. We thus have, in the preceding, a fairly comprehensive picture of the worldview presented within the oral tradition of Trinidad.

\section{Constructing an "(Anti)-Industrial" Worldview: The Minshall Mas 3.1 Trinidad Carnival Mas}

From the visual point of view, Mas is the most significant aspect of Trinidad Carnival. The word "Mas" etymologically is from the French "masque," and refers to the masks worn by members of the French plantocracy at their Carnival balls and parades in 19th-century Trinidad and Tobago. The grassroots Trinidad and Tobago costumed street parades emerged, in part, as a popular imitation and transformation of the white elite modes of celebrating Carnival. By the late 1970s, a primary feature of Mas is large costumed bands, created by specialist costume designers in competition with each other for large monetary prizes. These Mas bands often involved, in that era, thousands of masqueraders, presenting on themes ranging from fantasy to politics. Burton refers to the key role that Mas played in public consciousness, stating:

Many of the carnival masquerades of the 1950s could be and were interpreted as anti-colonial allegories ... and the growing disputes over federation and the advent of independence in 1963 (sic) added to the growing politicizing of carnival. After a brief honeymoon period, carnival began to reflect in some of its aspects the mounting disenchantment with independence, expressed above all through a passionate identification with "blackness," and "Africa" and through a parallel rejection of whiteness. ${ }^{28}$

\footnotetext{
27 Besson, Folklore and legends.

28 Burton, Afro-creole, 206-207.
} 
Burton goes on to point out that this period of black consciousness culminated in the highly politicized Mas bands of $1970 .^{29}$ This becomes the prelude to the serious disturbances, sometimes referred to as the Trinidad Black Power Revolution, which erupts in the immediate aftermath of Carnival and run into late April of that year. Mas continued to evolve subsequent to 1970. Burton notes that some commentators but not all claim that after the 1970 high point, political Mas began to recede as a significant element in Carnival. One explanation is government censorship. The major explanation put forward, however, is the economic prosperity experienced by Trinidad and Tobago between 1973 and the early 1980s as a result of the massive increase in world oil prices. ${ }^{30}$ This produced improvements in the economic lot of the mass of the ordinary population of the country. This meant a reduction in the inclination to protest against social, political and economic inequality and injustice, the core ingredient of political Mas.

Peter Minshall is a Mas band designer who emerges in the late 1970s. The Trilogy, in the eyes of many, his masterwork, is produced in 1983. Minshall himself describes these three costumed bands he designed as presenting a distinctive vision of Mas. Manuel et al. describes Minshall's vision of Mas as “... conceptual art, a unique sort of gargantuan street theatre rather than merely a festive parade around some whimsical theme." ${ }^{31}$ Minshall Mas, and in particular the 1983-85 Trilogy, represents a resurgence of "Mas with a message" which, as we have already observed, had been on the decline during the previous decade, since the 1970 Black Power Revolution. Commentators such as Manuel et al. all consider the Trilogy a groundbreaking departure from what had, by then, become standard fare in Trinidad and Tobago Carnival costume bands, feathers, beads, sequins and a mass of color. ${ }^{32}$

What follows is a detailed description of Minshall's Trilogy, derived in the main from the Narine video documentary on the Trilogy. This is used to construct the worldview which Minshall is presenting to the people in his "cup of beauty"/"golden calabash."

\section{The Data: The Minshall Trilogy (1983-85)}

The data on which this analysis is based is the Dalton Narine video documentary (2010) entitled "The Minshall Trilogy: A Modern Fable as Street Theatre." This documentary covers the groundbreaking Mas bands designed and presented by Peter Minshall over a period of three years. The Minshall Trilogy, on the face of it, is operating within an ephemeral medium involving a set of costume designs intended for Carnival revelry. The creator, Minshall, however, has a different take on his art. What follows is a description of the Trilogy. We shall, where appropriate, identify those aspects of the oral tradition, which have been used to form part of the Minshall's work. This description will, in the "Analysis" section, form the basis for a construction of the worldview being proposed by Minshall for Trinidad and Tobago, and for a comparison with the worldview of the oral folk tradition.

Minshall via the Trilogy uses this folk tradition as "the well of the people" into which it dips. We will, therefore, try to understand what constitutes "the cup of beauty" in which this water is presented back to the people. What is the worldview that lies behind what Minshall describes as the "... living, moving, dancing canvas that is painted by the people on the streets"? ${ }^{33}$ In the accounts, apart from what is visible in the video, we shall use two additional sources to give an account of what is taking place. The first is what we shall call the "band narrative," the narrative that accompanies the band as it crosses the stage. This narrative typically contextualizes and explains the band to the viewers. The second is from Minshall himself, in interviews done with him for the documentary, in which he himself seeks to explain his artistic creations.

\subsection{Part One: "River" (1983)}

Minshall presents his 1983 band, "River," as a two-act play enacted over the two days of Carnival - Act 1 performed on Carnival Monday and Act 2 on Carnival Tuesday. On Day 1, the band, representing the 26 rivers in Trinidad, is made up of several thousand masqueraders parading in costumes of white. These are people who live with the land and who take care of it. Above them is a long, continuous white strip canopy representing the rivers of the country in their original purity. "All of we is one from beginning of the river to the end." ${ }^{34}$ Represented here is a harmony between the physical environment, the river, in the form of the white canopy, and humans, clothed in white. Washerwoman leads the band, also in white.

\footnotetext{
${ }^{29}$ Burton, Afro-creole.

30 Ibid., 207.

31 Manuel et al., Caribbean Currents, 204.

32 Burton, Afro-creole, 206-207.

33 Narine, Minshall Trilogy.

34 Ibid.
} 
Washerwoman is symbolic of the forces of good that are attempting to maintain the harmony between the purity of the land and that of man's existence. It is, as well, a counter statement to the colorful and, from a Minshall point of view, meaningless Mas that had, by then, become the norm. Washerwoman, within the Minshall Mas, is an amalgam of Mama Dlo (Water Mother) and the Washerwoman of the folk tale tradition.

The band has another main character, Mancrab. He is an inverted, mechanical crab, with gleaming steel tentacles and limbs. According to Minshall, Mancrab is also symbolic of the advances in technology that are moving so fast that man cannot catch them..$^{35}$ Mancrab is designed to represent the threats of technology, weapons, and the crude animalistic side of humanity that eventually leads to environmental destruction. More narrowly, Mancrab represents the rapidly increasing industrialization of the country at the time. Mancrab also stands for the consumerism that is rampant during that period and the greed of the general population in an oil rich economy. This metallic mechanical demon creature of modern technology is defeated and banished in Act 1 on the first day. With a clear indication of red paint symbolic of the loss of life, the creature eventually is seen as killing himself with its high dependence on technological advancement.

In Act 2, performed on Day 2, Mancrab, using all the technological achievements of Man, makes a rainbow of color. This rainbow represents, according to Minshall, the pollution created in order to produce modern consumer items such as cars, refrigerators, and television sets. ${ }^{36}$ Mancrab throws this rainbow of color into the river. To get the benefits of technology, says Minshall, some part of the planet has to be destroyed. The masqueraders then go to the river with buckets, scoop up water and throw the rainbow on themselves. With the people swept away with/by color, Mancrab gains power. He kills Washerwoman and takes over.

This represents a commentary on the meaninglessness of the then dominant colorful "pretty Mas." Minshall is, by way of allusion, painting "Pretty Mas" as a surrogate for the spreading mass consumerism so typical of the period. What, on the first day, Monday, was a sea of people wearing white is now a mass of soiled white clothing smeared with color. The color is meaningless and ugly. The presentation leaves spectators questioning themselves and saying, "... on the Monday it looked so nice, ... so ... color." ${ }^{37}$ This presentation contrasts with the superficially pretty rainbow canopy on Day 2, reminiscent of the optical effects of an oil film on the surface of water, which proves to be deceptive. Once the people of the river seek to throw the pretty colors of the river on themselves, they become an indefinite dark mess, reminiscent of petroleum gushing from oil wells. Behind the deceptively pretty rainbow canopy, is this dark mess of indefinite color. There is now a longing for the purity that once was. How much prettier and better the masqueraders' and their rivers were when white!

\subsubsection{Commentary}

Mancrab symbolizes the process by which, according to Minshall, "if Man isn't careful, he is leading to his own destruction. ${ }^{38}$ The metallic, the engineered, and the mechanical are packaged, marketed, and consumed in rainbow camouflage. Mancrab, the technological, metallic production machine wins because people are willing to consume the colorful output of the production process. The colors of this consumerist rainbow blend into an indefinite darkness, which pollutes everything, the rivers and the people. The symbolic equivalent of Mancrab in the folk tradition is the hunter. It is from the depredations of the hunter, the indiscriminate killer, the human with metallic weapons and tools, that Papa Bwa protects the forest and the animals.

\subsection{Part Two: "Callaloo" (1984)}

The second Mas Band in the Trilogy, "Callaloo," is presented, as with "River" the previous year, as a two-act play to be performed over the two days of Carnival. It is an allegory. Mancrab is Satan, Washerwoman is the Virgin Mary, and Callaloo appears as Christ. The followers of Callaloo, the son of Washerwoman, are the Moon People. Another character is Hiroshima, so named by her father, Mancrab, who has sired her with the help of science. Washerwoman, in the meanwhile, has been resurrected as the Bird of Paradise.

On Day 1, Mancrab has defeated and killed Washerwoman only to find himself confronted by Washerwoman's son. He is "every man," Callaloo, a mixture of all the different racial \& ethnic groups in Trinidad and Tobago. The father of Callaloo is Papa Bwa, the protecting spirit of the forest. Callaloo is the name of a dish made with a wide variety of ingredients, all cooked together to become one. He is able to

\footnotetext{
${ }^{35}$ Narine, Minshall Trilogy.

${ }^{36}$ Ibid.

${ }^{37}$ Narine, Minshall Trilogy.

${ }^{38}$ Ibid.
} 
walk on water, this ability symbolizing humanity's close relationship with nature. Mancrab has to defeat Washerwoman's son, Callaloo, to attain absolute power.

The presentation on Day 1 follows the same pattern as Day 1 of the previous year's band, "River." There is a flow of people wearing white representing the rivers. The Children of the Moon, with the circles of their costumes giving them an abstract lunar quality, are celebrating Callaloo's victory over Mancrab in a festival of love and togetherness. To celebrate Callaloo's victory, an effigy of Mancrab is built and sent up in smoke. The Children of the Moon then dance in peace and in praise of Callaloo. They dance joining hearts and hands in unity.

Mancrab's rainbow colors have faded and the rivers run clear once more, clear and pure as do the people's hearts. Washerwoman has been resurrected as the Bird of Paradise, complete with accompanying supporting quotation read through the public address system as the band arrives on stage. The quote is from R.D. Laing's writing in psychiatry and, as some would say, mysticism, "I have seen the Bird of Paradise. She has spread herself before me and I shall never be the same again." ${ }^{39}$ In a shimmering bright orange costume, the Bird of Paradise symbolizes the purity of fire and of the sun. It leads a band of innocents-little children, representing love and hope for the future. During the festival of love and togetherness, the people prepare a callaloo stew, with all its many ingredients, which is served in every household. There are circles creating halos of light and love around each masquerader. A greater circle is made joining every heart and hand. But everything is not well. At the very end of the celebration, Madame Hiroshima, daughter of Mancrab, arrives. She is made with science. She casts a terrible shadow on the events that would follow the next day.

On Day 2, the Callaloo character in costume dances tic-tac-toe on the surface of the river. His followers, the children of the moon follow. Hiroshima tempts Callaloo, offering him absolute power. He refuses to be tempted. According to the band narrative, he only wants love. Mancrab is infuriated by Hiroshima's failure. He sends for help from his ancestors, the seven deadly sins. They advise that, to defeat Callaloo, man must be conquered as when man falls, so too will Callaloo. He will die of sadness. The plan works. Man is taken by the power Hiroshima offers. Callaloo grows weak, but struggles to stay standing.

People possessed by the seven deadly sins parade the streets. Mancrab's colors have grown bright again. This is the Kingdom of Hell. Huge totems to these seven sins are fashioned in bamboo, bush, and rope and paraded through the streets. Envy, anger, pride, greed, lust, gluttony are worshipped and given full praise. Last in the parade is sloth. These totems were designed to spray the masqueraders with dye, transforming them, as in the previous year, into a mass of dark color. Mancrab is powerful once more. The same pattern, in which a band, all in white, becomes a dirty dark mess, is played out with masqueraders spraying each other or being sprayed with colored paint.

\subsubsection{Commentary}

The Narine documentary points out that the Callaloo Mas Band broadens the ecological theme into one, which addresses the issue of love, the togetherness of man in the face of a possible nuclear holocaust. Here an anthropologist at the time Meryl James-Bryan mentions that the appearance of Callaloo coincided with the period of new oil wealth and all the challenges that that would bring. She suggests that the message from Minshall is to use a return to the cultural roots of the society as a means of confronting these challenges. ${ }^{40}$

Having somewhat exhausted characters within the folklore story tradition, Minshall falls back on a traditional Trinidadian dish, callaloo, as a basis for his extended modern folk-based narrative. The primary ingredient of the callaloo, the dasheen leaf, is heart shaped, and he employs this to symbolize love. The wide variety of ingredients, which become mixed together to create a callaloo dish, gives him a metaphor for unity in diversity. He asserts the single national identity, which all the races and ethnicities in Trinidad have merged into, particularly in the context of the artistic expression, which is Carnival. Callaloo, son of Washerwoman and Papa Bwa is the eternal symbol of unity, human with human, and human with nature. He is man's love for his fellow man and his love for Earth. Callaloo is the antithesis of evil, as represented by Mancrab. It is worthy of note that this time around, good, as represented by Callaloo, is not defeated by Mancrab or consumerism but by the seven deadly sins. This second band in the Trilogy is focusing on the connection between the environment and morality and spirituality.

\footnotetext{
${ }^{39}$ Laing, The Politics of the Experience, 190.

${ }^{40}$ Narine, Minshall Trilogy.
} 
The Bird of Paradise character created by Minshall is intriguing. Like Callaloo, this character has no antecedent in the oral folk tradition. The Bird of Paradise is, in fact, presented within the context of a quotation from R.D. Laing. The most relevant elements of the Laing work address the difficulties of knowing one's self and the external world. Associated with this is the notion that to know, one has to have an experience. This creates problems for communicating such knowing for someone who did not have the experience, which produces such knowing. Minshall suggests, through the use of the Laing quote, that he himself has seen the Bird of Paradise and that he has been transformed by the experience. Minshall is attempting to communicate his own knowing through a shared experience created by a mass participation art form, Trinidad and Tobago Carnival Mas. ${ }^{41}$

The Bird of Paradise represents a rather complicated choice of non-traditional character to appear in the narrative. One would have imagined, given Minshall's cultural and ecological predispositions, that the Bird of Paradise would be a bird indigenous to Trinidad and Tobago. It is, in fact, indigenous to Papua-New Guinea. In 1909, the British naturalist, William Ingram, bought a small islet off the coast of Tobago and, out of concern that the Bird of Paradise might become extinct in Papua-New Guinea, introduced the bird on that islet. That islet, whose original name was Little Tobago, came to be known as Bird of Paradise Island. In the 1920s, the naturalist made a gift of the islet to the government, on the understanding that it would remain a nature reserve for birds. The last sighting of the Bird of Paradise on the islet was in 1981. The Bird of Paradise is now considered extinct in this habitat. ${ }^{42}$ For Minshall, to see this rare bird in its isolated adopted habitat would have been a special experience indeed. The fact that he was seeing not a rare bird of the country but a refugee from a far off land receiving care and protection in an adopted land was exceedingly poignant. This was particularly so given Minshall's own stance, adopted in the Trilogy, as a defender of the natural environment.

\subsection{Part Three: "Golden Calabash" (1985)}

The Federico Garcia Lorca quote was specifically used by Minshall to comment on the last Mas Band of his Trilogy. His message is clear in that the population of Trinidad and Tobago is being provided with a story in the form of the common and popular art that is their own, i.e. Carnival Mas. However, once provided with this message, it is up to the population in their consumption of it through the experience of either participation or viewing, to understand the true tragedy that is created by rapid industrialization.

The story for this year deals with positive and negative, good and evil, ying and yang. Almost the whole band is plastic. This continues with the themes of consumerism and types of materials that are used in the packaging process. Within increasing industrialization and technology, plastics play a more dominant role in society. However, there are consequences to using increased amounts of plastics, which is alluded to in this story.

The Golden Calabash is a source of power. Whoever drinks from it can use that power for either good or evil. This is, of course, the Caribbean equivalent of the "cup of beauty." The water within it comes originally from the well of the people but is presented in the cup in a manner, which produces knowledge of self. The Golden Calabash presentation is represented by two competing sections, one representing the force of good, the other that of evil. The Lord of Light and the Princes of Darkness lead these, respectively. It is symbolically the apocalyptic horror. It requires the judges of the Mas Band competition as well as the people to decide by their response, whom the winner will be. There is the double entendre here of winner in the symbolic battle or winner of the Mas Band competition, and the question of which is real and which is fantasy, and the ability of one to influence the other. Who wins the battle would win the prize, the golden calabash. It is humanity who ultimately decides the fate of the environment.

\subsubsection{Commentary}

Minshall allows the people, through the Golden Calabash Mas Band, to recognize that there are two options facing humanity in the area of development. The first involves following the darkness. This can metaphorically be considered the uncontrolled role of development, where we become consumed/subsumed by the technology in an uncontrolled manner. This leads to environmental, social, and spiritual destruction. One of the costumed characters is The Adoration of Hiroshima, clearly a statement about the survival of humanity worldwide.

\footnotetext{
${ }^{41}$ Aronson, What is effective in restoration ecology, 67.

42 Ibid.
} 
The second option represents following the light, reflecting the harmony between man and nature, at the beginning of the Trilogy. The rivers run pure, represented by the white of the costumes and the unity of humanity is evident. The potential for environmental damage is recognized and care is taken to avoid it. The people have to choose, both in Mas and in life.

The Trilogy ends with the reiteration that Minshall, the "Masman" through his carnival displays, presents to the public their options and the consequences of their choices. He does so at a critical time in the history of Trinidad and Tobago, at the time when, in real life, the choices involving the shift in the economy to heavy industry are being made.

\section{Discussion}

It was "Mas" in the colloquial Trinidadian sense of complete controversy, as Minshall's Mas seemed to fly in the face of the meaningless mass of costumes of sequins, beads, and color, which had by then become the dominant for transforming the happy go lucky Trinidad and Tobago Carnival, as his critics saw it, into a canvas for serious messages. Within the documentary, we hear the scathing comments of a Mas Band designer. For him and many others, Minshall's use of Mas to convey a "serious" message was sacrilege. Within this outlook, the Carnival stage is a place for the public to "forget about their everyday concerns." ${ }^{43}$ By both word and deed, Minshall begged to differ. In 1983, at the beginning of the Trilogy, the Eric Williams inspired industrialization processes were well on the way. The fact that the villain of the piece, Mancrab, made out of iron and steel and by 1985, the last year of the Trilogy, the masqueraders were all clad in plastic, symbolizes the pervasion of the consumerist society but more so the waste that is associated with the use of these materials. The immediate issue of pollution of rivers was presented by the 1983 band, River, and in specific relation to that core material of traditional industrialization, iron and steel.

Callaloo, the second presentation in the Trilogy, broadened the problem from that of ecologically threatened rivers to that of morality. These involve relationships between humans, unity across races and cultures, and the love for other human beings. All of this stands as the antithesis to Mancrab's consuming technology power symbolized by the threat of destruction from nuclear war. The symbol of good, Callaloo, gets his power from Papa Bwa, his father, and Washerwoman, who symbolize oneness with nature. He is thus able to walk on water. Moral good is presented as rooted in an oneness with nature. The Callaloo presentation plays on a link between Christian and traditional symbols, as between the Virgin Mary and Washerwoman, particularly in her more traditional guise as Mama Glo/Water Mother, God and Papa Bwa/Forest Father, as well as Christ and Callaloo.

The implications of Minshall's take on the issue of the environment are clear. The issue of environmental pollution is a human one. This will only be dealt with successfully if human beings resolve their own relationships with each other. Environmental issues are ultimately those of people's moral values. On whether good or evil will prevail in Trinidad and Tobago, he makes no statement.

In Golden Calabash, 1985, the issue of the developmental choices is explored in two competing bands, representing good and evil respectively, to be judged by the public. The choice between the bands and the values they represent are in the hands of the people. But even as these decisions are being made, the actual context has also been transformed. Both good and evil are clothed in plastic, the material of the new industrial age.

The previous decade to Minshall's Trilogy placed the issue of environment and development squarely at the center of public and international discourse with the celebration of the first Earth day, the first UN conference on the environment in Stockholm and the rise of what is known today as the modern environmental movement. It was against this backdrop that Minshall's 1983-85 Trilogy serves, within the artistic domain, to make the issue easily accessible to the general public of the country through popular culture. His message, "though shall now rob the future," in relation to the rampant exploitation and destruction of his country's natural resources in the name of development, is extremely clear.

\subsection{Inside the Cup of Beauty/Golden Calabash}

What then is the worldview that Minshall, having drawn it from the well of traditional folklore, is now presenting back to the people in a cup fashioned by his Trilogy? The same characteristics we used to reconstruct the worldview of the traditional culture can be employed in identifying the worldview being (re) presented to the people in Minshall's cup of beauty/golden calabash.

\footnotetext{
${ }^{43}$ Narine, Minshall Trilogy.
} 
Characteristic a), his explanation of the world, is clearly present. For Minshall, for humanity to exist, it must do so in harmony with nature.

Present is characteristic b), his predictions about the future of the world, are also presented in the Trilogy. Minshall lays these out as choices that humanity has to make. The Trilogy places two options before us. The first is to adopt environmentally unfriendly industrialization and consumerism, as well as the destruction of the earth through nuclear war. The other is a development approach driven by a commitment to survive through protecting the environment.

Minshall in the Trilogy also demonstrates the presence of characteristic c), ethics. Here, we see his commitment to the rejection of the deadly sins. In addition, he makes Callaloo the embodiment of goodness and unity. His ethical stance is clear.

Characteristic d), his theory of action, is also present. This involves his art form, street theatre and Mas, which would have people know through experiencing Mas. Once they know, they can make the appropriate choices in real life. Leaving the public and the judges to decide which of the two band sections, the one led by the Lord of Light and the other by the Prince of Darkness, wins, hands over the decision making, metaphorically and by extension literally, to the people.

In relation to characteristic e) epistemology, he presents consumerism, as well as the deadly sins, as false. This falseness is a result of them violating the principle of oneness with nature, the very essence of humanity's existence. Like the rainbow of color created by polluting oil on the surface of the rivers, these are optical illusions. They obscure the dark mess that these sins really are.

The final characteristic is f), etiology. Minshall's use of predominantly traditional motifs suggests that this is knowledge, which is coming from tradition handed down from generation to generation. And, in communicating a sense of where things begin, with the river, we are presented with a worldview, which sees the beginning of everything in flowing water. This is manifested in the "in the beginning" presentation at the start of River, with the 26 rivers all-flowing pure and clear. Minshall's worldview is constructed using binary opposites, good and evil, white and black. These are presented as choices which humanity constantly has to make.

Minshall does as he promises. He takes a traditional worldview from the well of the people, modernizes it and presents it back to the people from whom he took it. It comes to them in a Golden Calabash. As to what is the actual value of this gift, and its impact on the real world, Minshall has left the people who drink it to decide.

\subsection{Postscript}

We would do Minshall a disservice if we did not, at least briefly, examine the actual real-world effect of his work. The Trilogy was effective at the communicative level in that it reached out to the mass of the population. Commenting on mas, with specific reference to Minshall and the Trilogy, Manuel et al. states, “... on the whole, there is nothing like Trinidad Carnival. It's popularity can be gauged by the fact that the Monday and Tuesday events in Port-of-Spain generally draw around seven hundred thousand participants and reveled, about two-thirds of the entire country's population." ${ }^{44}$ The Minshall bands, "River" in 1983 and "Golden Calabash" in 1985, won the People's Choice award, decided on by the level of public acclaim. He also won prizes awarded by the judges for individual King and Queen costumes in all three years, but not the band prize. This he himself seems to have interpreted as a rejection by the Carnival establishment of his "Mas with a message" bands. ${ }^{45}$

Given the undoubted popularity and effectiveness of the message, however, the test of Minshall's artistic success, using his own measuring rod, is how effective this has been in changing reality. According to Boden et al., Trinidad and Tobago is now the world's second largest per capita emitter of carbon dioxide, topped only by Qatar. ${ }^{46}$ This fact, on its own, suggests that Minshall failed dismally. There are other facts, however, which counter this negative assessment. In the first decade of the 21st-century, there was a new thrust in the direction of further heavy industry, this time in the form of two aluminum smelters. On this occasion, there is considerable debate about the effects of these developments on the environment. In fact, a strong environmental lobby developed and, in combination with the communities that were located near to the

\footnotetext{
${ }^{44}$ Manuel et al., Caribbean Currents, 205.

${ }_{45}$ Boden et al., Global, Regional, and National Fossil-Fuel $\mathrm{CO}_{2}$ Emissions, http://cdiac.ornl.gov/trends/emis/tre_amd.html.

${ }^{46}$ Ibid.
} 
proposed industrial developments, launched a successful campaign to prevent these projects from being implemented ${ }^{47}$ (Richards, 2010).

The charge that Minshall has been ineffective may, thus, only be valid if one is impatient and one's time horizon is short. An artist's impact on popular consciousness arguably has a long gestation period. Thus, when action by the public, potentially attributable to such artistic work, is taken, much time has passed. This time lag makes it difficult, with any certainty, to attribute such action to its putative artistic source.

\section{Competing Interests}

The authors have no competing interests to declare.

\section{References}

Aronson James, and Ausenda Giorgio. (ed.) 2003. What is effective in restoration ecology and how to measure it, On Effectiveness: Studies on the Nature of War. Boydell Press, Woodbridge.

Besson, Gerard. 2001. Folklore and legends of Trinidad and Tobago. Paria Publishing Company Ltd, San Juan, Trinidad.

Boden, T. A., G. Marland, and R. J. Andres. 2011. Global, Regional, and National Fossil-Fuel $\mathrm{CO}_{2}$ Emissions. Carbon Dioxide Information Analysis Center website.

Burton, Robert. 1997. Afro-creole: Power, Opposition and Play in the Caribbean. Cornell University Press, Ithaca.

Carroll, Karanja Keita. 2010. A Genealogical Analysis of the Worldview Framework in African-centered Psychology. Journal of Pan African Studies, 3(8): 109-134.

Fanon, Frantz. 1968. The Wretched of the Earth. Grove Press, New York.

Inglehart, Ronald. 1997. Modernisation and PostModernisation: Cultural, Economic and Political Change in 43 Societies. Princeton University Press, Princeton.

Johnson, Kathryn A., Eric D. Hill, and Adam B. Cohen. 2011. Integrating the Study of Culture and Religion: Toward a Psychology of Worldview, Social and Personality Psychology Compass, 5(3): 137-152. DOI: https://doi.org/10.1111/j.1751-9004.2010.00339.x

Kambon, Khafra, Ken Valley. 2011. black power and Africa, Trinidad Express. May 19.

Laing, Robert D. 1967. The Politics of the Experience. Ballantine Books, New York.

Manuel, Peter, Kenneth Bilby, and Michael Jargey. 1995. Caribbean Currents: Caribbean Music From Rumba to Reggae. Temple University Press, Philadelphia.

Pasley, Victoria. 2001. The Black Power Movement in Trinidad: An Exploration of Gender and Cultural Changes and the Development of a Feminist Consciousness. Journal of International Women's Studies, 3(1): 24-40.

Richards, Peter. 2010. Trinidad scraps controversial smelter. Inter Press Service News Agency. September 24.

The Minshall Trilogy: A Modern Fable as Street Theatre. 2010. Directed by Dalton Narine, Create Space Studio, Port of Spain, Trinidad and Tobago.

Thoumi, Francisco E. 1989. Thwarted Comparative Advantage, Economic Policy and Industrialization in the Dominican Republic and Trinidad and Tobago. Journal of Interamerican Studies and World Affairs, 3(1\&2): 147-168. DOI: https://doi.org/10.2307/165915

Toelken, Barre. 1996. The Dynamics of Folklore. Utah State University Press, Logan. DOI: https://doi. org/10.2307/j.ctt46nrng

wa Thiong'o, Ngũgĩ. 1983. Barrel of a Pen: Resistance to Repression in Neo-Colonial Kenya. New Beacon Books, London.

\footnotetext{
${ }^{47}$ Peter Richards, "Trinidad scraps controversial smelter," Inter Press Service News Agency, September 24, 2010, http://www.ipsnews.
} net/2010/09/trinidad-scraps-controversial-smelter/. 
How to cite this article: Devonish, Hubert and April Baptiste. 2019. Life Masquerading as Art: The Activist Artist Takes on Development v. Environment. Anthurium, 15(1): 2, 1-14.

Published: 12 February 2019

Copyright: (c) 2019 The Author(s). This is an open-access article distributed under the terms of the Creative Commons Attribution 4.0 International License (CC-BY 4.0), which permits unrestricted use, distribution, and reproduction in any medium, provided the original author and source are credited. See http://creativecommons.org/licenses/by/4.0/. 